\title{
Implementasi Kebijakan Sekolah Ramah Anak Dalam Mewujudkan Kota Layak Anak di Kota Depok
}

\author{
${ }^{1}$ Safitri Rangkuti, ${ }^{2}$ Irfan Ridwan Maksum \\ ${ }^{12}$ Program Pasca Sarjana Fakultas Ilmu Administrasi \\ Universitas Indonesia, Jakarta,Indonesia \\ Email:qqrangkuti@gmail.com,irm01@yahoo.com
}

Received: 11 Mei 2019; Revised: 12 Mei 2019; Accepted: 22 Mei 2019

\begin{abstract}
Child-friendly and child-based schools are an effort to fulfill children's rights and provide quality education for children. This study aims to explain the implementation of Child Friendly School Policies established by the Ministry of Female Empowerment and Child Protection and to analyze the supporting and inhibiting factors for the implementation of Child Friendly School Policies in SMP Negeri 6 Depok. This study used a qualitative method that shows the implementation of the Child Friendly School Policy in SMPN 6 Depok been going well, assessed in the context of the process, results (output), impact (outcomes) and causality (causal connection).The factors that support the implementation of the Child Friendly School Policy at SMP Negeri 6 Depok are good and smooth communication, attitudes and commitment of all school people, coordination between the Depok Government and the School and the positive support of all school members, parents, surrounding communities. However, there are still obstacles, namely the limited school budget and the number of teachers, and the density of teacher activities that have caused the implementation of policies to be not optimal. For facilitating the implementation of child-friendly school policies, collaboration between central government and local government, schools and communities is needed.
\end{abstract}

Keywords: Policy Implementation; Rights; Protection; Child

\begin{abstract}
Abstrak
Sekolah yang ramah anak dan berbasis hak anak merupakan upaya memenuhi hak-hak anak dan memberi pendidikan yang berkualitas bagi anak. Penelitian ini bertujuan untuk menjelaskan implementasi Kebijakan Sekolah Ramah Anak yang ditetapkan oleh Kementerian Pemberdayaan Perempuan dan Perlindungan Anak dan menganalisis faktor pendukung dan penghambat implementasi Kebijakan Sekolah Ramah Anak di Kota Depok. Penelitian ini menggunakan metode kualitatif yang menunjukan implementasi Kebijakan Sekolah Ramah Anak di SMP Negeri 6 Depok sudah berjalan baik, dinilai dalam konteks proses, hasil (output), dampak (outcome) dan hubungan sebab akibat (causal connection). Faktor-faktor yang mendukung implementasi Kebijakan Sekolah Ramah Anak di Kota Depok adalah komunikasi yang baik dan lancar, sikap dan komitmen seluruh warga sekolah, koordinasi antar Pemda Depok dengan Sekolah serta adanya dukungan positif seluruh warga sekolah, orang tua, masyarakat sekitar. Namun masih terdapat faktor penghambat yaitu terbatasnya anggaran sekolah dan jumlah guru serta padatnya aktivitas guru menyebabkan pelaksanaan kebijakan belum optimal. Untuk memperlancar implementasi kebijakan sekolah ramah anak dibutuhkan kerjasama antara seluruh pihak baik pemerintah pusat dan daerah, sekolah dan masyarakat
\end{abstract}

Kata Kunci: Implementasi Kebijakan; Hak; Perlindungan; Anak

Link DOI : http://dx.doi.org/10.31314/pjia.8.1.38-52.2019

38 Copyright (C) 2019, Publik (Jurnal Ilmu Administrasi), Under the license CC BY-SA 4.0 ISSN: 2301-573X (Print), ISSN: 2581-2084 (Online) 


\section{PENDAHULUAN}

Konvensi Hak Anak telah mengamanatkan seluruh bangsa di dunia untuk memenuhi hak-hak anak dalam upaya menciptakan anak yang sehat, cerdas, ceria, berakhlak mulia dan cinta tanah air. Hal ini merupakan tantangan yang berat bagi pemerintah Indonesia dalam mewujudkan pemenuhan hak anak dan perlindungan anak namun dengan tekad yang bulat, Indonesia telah meratifikasi Konvensi Hak Anak melalui Keputusan Presiden Nomor 36 Tahun 1990 tentang Ratifikasi Konvensi Hak Anak sebagai upaya memenuhi, melindungi dan menghormati hak anak dan berdasarkan latar belakang tersebut pada tahun 2016 Kementerian Pemberdayaan Perempuan dan Perlindungan Anak mengeluarkan Kebijakan Kabupaten/Kota Layak Anak (KLA) dan pada tahun 2009 menerbitkan Peraturan Menteri PPPA Nomor 2 Tahun 2009 tentang Kebijakan Kota Layak Anak. Tujuan akhir yang hendak dicapai dalam Kebijakan Kota Layak Anak (KLA) adalah Indonesia mencapai kondisi Indonesia Layak Anak (IDOLA) pada tahun 2030. Tujuan ini juga sejalan dengan program PPB yaitu Sustainable Development Goals (SDGs) pada tahun 2030.

Terciptanya anak Indonesia yang sehat, cerdas, ceria, berakhlak mulia dan cinta tanah air dalam Sistem Pendidikan Nasional selaras dengan isi Pasal 29 ayat (1) Konvensi Hak Anak yang memfokuskan pada pendidikan yang bertujuan untuk mengembangkan kepribadian, bakat, kemampuan mental dan fisik anak secara optimal. Tekad bulat bangsa Indonesia untuk memenuhi hak anak dan melindungi anak khususnya di bidang Pendidikan tercantum dalam pasal 28C Undang-Undang Dasar Negara
Republik Indonesia 1945 menyebutkan bahwa "setiap anak berhak mengembangkan diri melalui pemenuhan kebutuhan dasar, berhak mendapat pendidikan dasar dan memperoleh manfaat dari ilmu pengetahuan dan teknologi, seni dan budaya, demi meningkatkan kualitas hidupnya dan demi kesejahteraan umat manusia" dan tata cara pelaksanaannya diatur pada pasal 9 ayat (1) Undangundang Nomor 23 Tahun 2002 tentang Perlindungan Anak yang menyebutkan bahwa "Setiap anak berhak memperolah pendidikan dan pengajaran dalam rangka pengembangan pribadinya dan tingkat kecerdasannya sesuai dengan minat dan bakat." Hal yang sama juga dijelaskan dalam Pasal 29 ayat (2) UUD 1945 bahwa "setiap anak berhak atas kelangsungan hidup, tumbuh dan berkembang serta berhak atas perlindungan dari kekerasan dan diskriminasi.

Untuk menjamin pemenuhan hak anak seperti kesehatan, keamanan dan kenyamanan anak di sekolah, Kementerian Pemberdayaan Perempuan dan Perlindungan Anak mengeluarkan Peraturan Menteri PPPA Nomor 8 Tahun 2014 tentang Kebijakan Sekolah Ramah Anak yang merupakan bagian dari indikator Kebijakan Kabupaten/Kota Layak Anak sebagaimana diatur dalam Peraturan Menteri Pemberdayaan Perempuan dan Perlindungan Anak (PPPA) No. 12 Tahun 2011 tentang Indikator Kabupaten/Kota Layak Anak (KLA) Pasal 11 menyebutkan bahwa "Klaster Pendidikan, Pemanfaatan Waktu Luang dan Kegiatan Budaya meliputi: (a) angka partisipasi Pendidikan usia dini; (b) persentase wajib belajar Pendidikan 12 (dua belas) tahun; (c) persentase Sekolah Ramah Anak; (d) Jumlah sekolah yang

Copyright (C) 2019, Publik (Jurnal Ilmu Administrasi), Under the license CC BY-SA 4.0 ISSN: 2301-573X (Print), ISSN: 2581-2084 (Online) 
memiliki program, sarana dan prasarana perjalanan masuk ke dan dari sekolah dan (e) tersedia fasilitas untuk kegiatan kreatif dan rekreatif yang ramah anak, di luar sekolah, yang dapat diakses semua anak".

Sekolah Ramah Anak merupakan sebuah konsep yang ideal untuk anak usia sekolah. Pada sekolah ramah anak semua pendidikan berpusat pada anak dan proses belajar harus didukung oleh keadaan sosial, fisik dan emosional yang positif, sehat dan aman. UNICEF telah mengembangkan kerangka kerja sistem dan pendidikan sekolah berbasis hak anak yang memiliki ciri yaitu "inklusif, sehat dan protektif untuk semua anak, efektif dengan anak-anak, dan terlibat dengan keluarga, masyarakat dan anak-anak" (Shaeffer, 1999). Dalam kerangka ini:

- Sekolah ramah anak memastikan setiap anak lingkungan yang aman secara fisik, aman secara emosional dan memungkinkan secara psikologis.

- Guru adalah satu-satunya faktor terpenting dalam menciptakan ruang kelas yang efektif dan inklusif.

- Sekolah yang ramah anak mengakui, mendorong dan mendukung pertumbuhan kapasitas anak-anak sebagai pembelajar dengan memberikan budaya sekolah, perilaku mengajar dan konten kurikulum yang berfokus pada pembelajaran dan pelajar.

- Kemampuan sekolah untuk menjadi dan menyebut dirinya ramah anak berhubungan langsung dengan dukungan, partisipasi, dan kolaborasi yang diterimanya dari keluarga.

- Sekolah ramah anak bertujuan untuk mengembangkan lingkungan belajar di mana anak-anak termotivasi dan dapat belajar. Anggota sekolah yang ramah dan menyambut anak-anak dan memperhatikan semua kebutuhan kesehatan dan keselamatan mereka.

Tujuan dari dikembangkannya Sekolah Ramah Anak antara lain mencegah kekerasan terhadap anak dan warga sekolah lainnya, mencegah anak mendapatkan kesakitan karena keracunan makan dan lingkungan yang tidak sehat, mencegah kecelakaan di sekolah yang disebabkan prasarana maupun bencana alam, mencegah anak menjadi perokok dan pengguna Napza, menciptakan hubungan antar warga sekolah yang lebih baik, akrab dan berkualitas, memudahkan pemantauan kondisi anak selama anak berada di sekolah, memudahkan mencapai tujuan pendidikan, menciptakan lingkungan yang hijau dan tertata, ciri khusus anak menjadi lebih betah di sekolah, anak terbiasa dengan pembiasaan pembiasaan positif.

Indikator Sekolah Ramah Anak meliputi enam komponen penting yaitu : (1) Kebijakan Sekolah Ramah Anak (SRA); (2) Pelaksanaan Kurikulum; (3) Pendidikan dan Tenaga Kependidikan terlatih Hak-Hak Anak; (4) Sarana dan Prasarana Sekolah Ramah Anak; (5) Partisipasi Anak, (6) Partisipasi Orang tua, Lembaga Masyarakat, Dunia Usaha, Pemangku Kepentingan lainnya dan Alumni.

Hasil yang diharapkan dari terlaksananya Kebijakan Sekolah Ramah Anak adalah terwujudnya sekolah yang aman dan menyenangkan bagi peserta didik karena bebas dari kekerasan yang diterjadi antara peserta didik maupun kekerasan yang dilakukan oleh pendidik

40 Copyright () 2019, Publik (Jurnal Ilmu Administrasi), Under the license CC BY-SA 4.0 ISSN: 2301-573X (Print), ISSN: 2581-2084 (Online) 
dan tenaga kependidikan; terbentuknya perilaku pendidik dan tenaga kependidikan yang berprespektif anak; penerapan disiplin positif yang membantu anak untuk berfikir dan bertindak benar untuk anak yang dianggap melalaikan kewajibannya bukan sanksi atau hukuman yang selama ini dilakukan dan meningkatkan partisipasi peserta didik dalam proses pembelajaran dan dalam pengambilan keputusan di sekolah.

Implementasi Kebijakan Sekolah Ramah Anak di Kota Depok telah dimulai sejak tahun 2016 dengan dikeluarkannya Surat Keputusan Kepala Diknas Pendidikan Kota Depok Nomor: 421/4814Disdik/2016 tentang Penetapan Sekolah Ramah Anak Kota Depok Sebagai Penyelenggara Pendidikan Sekolah Ramah Anak Tahun Pelajaran 2016/2017, pada awal ditetapkannya Sekolah Ramah Anak di Kota Depok baru terdapat 116 Sekolah ramah anak. Keberhasilan implementasi Kebijakan Sekolah Ramah Anak menjadi hal penting dalam mewujudkan Kota Depok sebagai Kota Layak Anak.

Maraknya kasus kekerasan di lingkungan sekolah menjadi sorotan bagi pemerintah untuk mengevaluasi pelaksanaan Kebijakan Sekolah Ramah Anak. Berdasarkan data Komisi Perlindungan Anak Indonesia (KPAI) pada tahun 2018, Jumlah pengaduan kekerasan di lingkungan Pendidikan terdapat sebanyak 451 kasus atau 9\% dari total pengaduan. Dari fakta yang ada di lapangan dapat disimpulkan bahwa sekolah belum bisa menjadi tempat yang memberikan keamanan dan kenyamanan bagi anak padahal waktu anak berada di lingkungan sekolah kurang lebih 8 (delapan) jam atau 1/3 (sepertiga) hari. Hal ini merupakan gambaran bahwa sampai dengan saat ini kondisi anak di Indonesia ternyata masih terancam kehidupannya sehingga belum dapat dikatakan Indonesia Layak Anak.

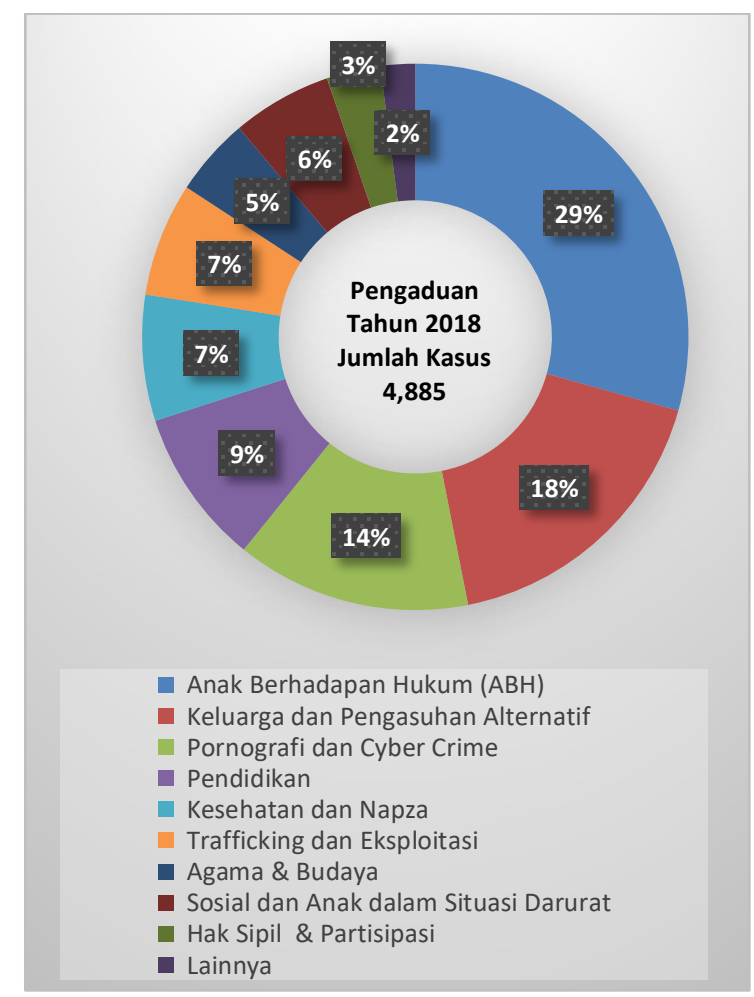

Sumber: diolah dari Bidang Data Informasi dan Pengaduan KPAI 2018.

\section{Gambar 1 Prosentase Jumlah Pengaduan Tahun 2018}

Dikutip dari Republika.co.id, "Disdik Kota Depok targetkan seluruh sekolah ramah anak tahun 2020", namun saat ini permasalahan kekerasan di sekolah masih terjadi di Kota Depok bahkan ditemui kasus kekerasan terjadi di Sekolah, bahkan pada sekolah yang telah menyandang Sekolah Ramah Anak. Selain kekerasan di dunia Pendidikan, sampai saat ini banyak sekolah ramah anak di Depok yang belum memiliki rencana program/kegiatan terkait Kebijakan Sekolah Ramah Anak (SRA), sehingga masih hanya sekedar predikat saja karena pada kenyataannya belum 
seluruhnya sekolah yang telah ditetapkan sebagai Sekolah Ramah Anak telah menjalankan Kebijakan Sekolah Ramah Anak.

$\begin{array}{lrr}\text { Berdasarkan permasalahan yang } \\ \text { telah dijelaskan sebelumnya perlu } \\ \text { dilakukan penelitian tentang implementasi } \\ \text { Kebijakan Sekolah Ramah Anak di } & \text { Kota } \\ \text { Depok dan faktor-faktor yang }\end{array}$ mempengaruhi implementasi Kebijakan Sekolah Ramah Anak di Kota Depok dengan mengambil lokasi penelitian di SMP Negeri 6 Depok yang merupakan salah satu sekolah yang menjadi model percontohan sebagai Sekolah Ramah Anak pada tahun 2016 oleh Dinas Pendidikan Kota Depok. SMP Negeri 6 Depok dipilih menjadi sampel penelitian karena memiliki berbagai macam prestasi antara lain Sekolah Sehat, Sekolah Adiwiyata dan salah satu sekolah favorit di Kota Depok.

Beberapa penelitian mengenai implementasi sekolah ramah anak telah dilakukan diantaranya penelitian dari Wuryandani, Wuri, (2018) dalam "Implementasi Pemenuhan Hak Anak melalui Sekolah Ramah Anak" yang menjelaskan perencanaan dan pelaksanaan pembelajaran di sekolah harus menyesuaikan dengan kebutuhan dan kondisi atau kareateristik anak sehingga proses belajar menjadi menyenangkan bagi anak dan proses pembelajaran juga harus memperhatikan layanan inklusi untuk anak berkebutuhan khusus. Selain itu penelitian yang sama dari Artadianti (2017) menganalisis tentang "Implementasi Sekolah Ramah Anak (SRA) pada Sekolah Percontohan di SD Pekunden 01 Kota Semarang Sebagai Upaya Untuk Mendukung Program Kota Layak Anak
(KLA)" menyimpulkan bahwa implementasi Sekolah Ramah Anak (SRA) belum optimal masih banyak hambatan seperti masih terjadinya kekerasan di sekolah yang dilakukan guru atau murid, kurangnya pengawasan dari orang tua, pengaruh lingkungan yang menyebabkan anak berhadapan dengan hukum dan tidak tersedianya SDM yang membimbing murid secara fisik. Penelitian yang serupa dilakukan oleh Ranti Eka Utari (2017), tentang "Implementasi Program Sekolah Ramah Anak di SMP Negeri 1 Tempuran Kabupaten Magelang" yang menemukan bahwa faktor yang mendukung Implementasi Program Sekolah Ramah Anak adalah sumber daya manusia, sarana dan prasarana dan sumber daya finansial sedangkan faktor yang menghambat adalah kondisi lingkungan yang berupa limbah asap pabrik berbahaya untuk kesehatan anak.

Ayu Kartika Sari, (2017) dalam penelitiannya tentang "Implementasi Program Sekolah Ramah Anak dalam Penangulangan Kekerasan pada Anak di SDN 3 Panggung Rejo Kabupaten Pringsewu" menemukan bahwa implementasi program Sekolah Ramah Anak sudah berjalan efektif namun terdapat beberapa masalah pada awal pelaksanaan program dalam menyatukan presepsi dan mendorong/merangkul warga sekolah untuk merubah kebiasaankebiasaan sedangkan penelitian dari Wahyu Intan Yuliani (2016) mengenai "Implementasi Peraturan Wali Kota Surakarta Nomor 28D Tahun 2014 Tentang Sekolah Ramah Anak (Studi di SD Muhammadiyah 16 Karangasem dan SD Muhammadiyah Program Khusus (PK) 
Kota Barat"menemukan bahwa kedua sekolah telah melalui tahapan Sosialisasi, pelaksanaan kebijakan, hasil kebijakan namun dalam pelaksanaan Sekolah Ramah Anak ini masih terdapat beberapa masalah diantaranya sikap pengajaran guru masih belum beradaptasi dengan kebijakan Sekolah Ramah Anak dan fasilitas dan anggaran yang belum memenuhi standar.

Penelitian terdahulu menjadi pedoman bagi penulis dalam melakukan analisis implementasi Kebijakan Sekolah Ramah Anak dalam mewujudkan Kota Layak Anak di kota Depok. Penelitian tentang Implementasi Sekolah Ramah Anak di Kota Depok sampai dengan saat ini belum pernah dilakukan oleh peneliti sebelumnya. Dengan adanya penelitian ini dapat memberikan gambaran tentang implementasi Kebijakan Sekolah Ramah Anak di Kota Depok dan faktor-faktor yang mempengaruhi implementasi Kebijakan Sekolah Ramah Anak. Harapannya penelitian ini dapat memberikan saran dan solusi kepada para pihak terkait baik pemerintah maupun masyarakat sehingga implementasi Kebijakan Sekolah Ramah Anak di Kota Depok dapat memberikan hasil dan dampak yang positif.

Implementasi kebijakan pada dasarnya adalah cara sebuah kebijakan dapat mencapai tujuannya. Umumnya berbagai kondisi ideal yang tercantum dalam suatu kebijakan namun ketika harus berhadapan dengan berbagai kenyataan di lapangan menjadi sulit untuk direalisasikan. Fenomena ini sering ditemukan pada saat implementasi kebijakan sehingga banyak kegagalan berbagai kebijakan dan program pemerintah pada saat dijalankan yang harus dianalisis kembali oleh pemerintah.
Berhasil atau gagalnya implementasi suatu kebijakan dipengaruhi oleh variable atau faktor yang saling berhubungan satu sama lain.

Goerge Edward III menjelaskan bahwa ada empat faktor yang berpengaruh dalam implementasi kebijakan yaitu:

1) Komunikasi

Komunikasi yang baik merupakan faktor penting untuk menyampaikan tujuan dan sasaran kebijakan kepada para implementor sehingga tidak ada kesalahpahaman antara pembuat kebijakan dengan pelaksana kebijakan.

2) Sumber daya

Pelaksanaan kebijakan harus didukung dengan sumber daya yang terdiri dari sumber daya manusia, informasi (mencakup cara pelaksanaan kebijakan dan kepatuhan para implementor), wewenang (kewenangan implementor dalam melaksanakan kebijakan yang ditetapkan) yang baik dan fasilitas yang mendukung kelancar proses pelaksanaan kebijakan

3) Disposisi

Karakteristik, sikap, watak yang dimiliki oleh implementor merupakan unsur penting dalam implementasi kebijakan seperti komitmen, kejujuran dan sifat demokratis. Jika implementor memiliki sikap positif terhadap kebijakan merupakan potensi untuk melaksanakan apa yang menjadi sasaran kebijakan.

4) Struktur birokrasi.

Struktur birokrasi yang panjang akan membuat prosedur birokrasi yang rumit dan kompleks. Dalam implementasi 
kebijakan diperlukan struktur birokrasi yang jelas, efektif dan efisien.

Pendapat yang hampir sama juga dikemukakan oleh G. Shabbir Cheema dan Dennis A. Rodinelli bahwa terdapat beberapa faktor yang mempengaruhi yaitu:

(1) Kondisi lingkungan;

Kondisi lingkungan sangat mempengaruhi implementasi kebijakan yang dimaksud lingkungan mencakup lingkungan sosio kultural serta keterlibatan penerima kebijakan/program

(2) Hubungan antar organisasi;

Dalam banyak program, implementasi suatu kebijakan/program perlu dukungan dan koordinasi dengan instansi lain. Untuk itu diperlukan koordinasi dan kerjasama antar instansi bagi keberhasilan suatu kebijakan/program.

(3) Sumber daya organisasi untuk implementasi kebijakan/program;

Tanpa didukung sumber daya baik sumber daya manusia maupun sumber daya lainnya pelaksanaan kebijakan akan mengalami keterbatasan dan hambatan sehingga mempengaruhi keberhasilan implementasi kebijakan.

(4) Karakteristik dan kemampuan agen pelaksana.

Yang dimaksud dengan karateristrik dan kemampuan adalah mencakup struktur birokrasi, norma-norma dan pola-pola hubungan yang terjadi dalam birokrasi, yang semuanya itu akan mempengaruhi implementasi kebijakan/program.

Berdasarkan teori yang telah dijelaskan diatas maka dalam penelitian ini akan menganalisis Implementasi Kebijakan Sekolah Ramah Anak dari empat ruang lingkup yaitu proses, hasil, dampak dan hubungan sebab akibat dan untuk menganalisis faktor-faktor yang mempengaruhi Implementasi Kebijakan Sekolah Ramah Anak dengan menggunakan variable antara lain; Komunikasi, Sumber Daya, Disposisi (Karakteristik dan Kemampuan Agen Pelaksana), Struktur Birokrasi, Hubungan antar organisasi dan Kondisi Lingkungan dalam menjawab pertanyaan penelitian.

\section{METODE PENELITIAN}

Penelitian Implementasi Kebijakan Sekolah Ramah Anak dalam Mewujudkan Kota Layak Anak di Kota Depok ini menggunakan pendekatan post postivis dengan metode pengumpulan data kualitatif. Pendekatan ini digunakan oleh penulis untuk menggali informasi dari narasumber atau para informan yang membantu dalam menganalisis Implementasi Kebijakan Sekolah Ramah Anak di Kota Depok.

Informan dalam penelitian ini adalah Dinas Pemberdayaan Anak Masyarakat dan Keluarga, Dinas Pendidikan, Kepala Sekolah, Guru, Anak Murid, Orang Tua, KPAI dan Psikolog. Penelitian dilakukan tahun 2019 dengan lokasi penelitian SMP Negeri 6, Cilodong, Kota Depok.

Teknik pengumpulan data yang digunakan untuk mendapatkan informasi dan data dilakukan melalui wawancara, studi kepustakaan (literature), dokumentasi, observasi. Dalam menganalisis data dilakukan dengan pengumpulan data, reduksi data, penyajian 
data dan penarikan kesimpulan. Berdasarkan hal tersebut penelitian ini menghasilkan informasi dan data-data lapangan tentang implementasi Kebijakan Sekolah Ramah Anak dan faktor yang mempengaruhi implementasi Kebijakan Sekolah Ramah Anak di SMP Negeri 6 Depok.

Lokasi penelitian adalah SMP Negeri 6 Depok karena sekolah yang berada di Kecamatan Cilodong Depok Jawa Barat. Pemilihan lokasi penelitian ini karena di sekolah tersebut karena Kota Depok merupakan salah satu Kota Layak Anak kategori Nindya pada tahun 2017 dan 2018 dan SMP Negeri 6 Depok merupakan sekolah yang telah menerapkan Kebijakan Sekolah Ramah Anak seperti antara lain telah menjadi sekolah inklusi, adanya kebijakan anti kekerasan, pembinaan guru tentang anti kekerasan, sarana prasarana sekolah cukup mendukung sekolah ramah anak dan beberapa indikator pendukung lainnya. SMP Negeri 6 Depok merupakan salah satu sekolah yang dipilih sebagai percontohan Sekolah Ramah Anak pada tahun 2016.

\section{HASIL DAN PEMBAHASAN}

\section{Gambaran Implementasi Kebijakan} Sekolah Ramah Anak Di SMPN 6 Depok Dalam Aspek Proses, Hasil, Dampak dan Hubungan Sebab Akibat.

Kebijakan Sekolah Ramah Anak (SRA) sudah diterapkan di SMP Negeri 6 Depok sejak tahun 2016. Dinas Pendidikan Kota Depok menunjuk 116 sekolah dari tingkat Sekolah Dasar sampai Sekolah Menengah Atas sebagai percontohan Sekolah Ramah Anak di Kota Depok melalui Surat Keputusan Kepala Diknas Pendidikan Kota Depok Nomor: 421/4814-
Disdik/2016 tentang Penetapan Sekolah Ramah Anak Kota Depok Sebagai Penyelenggara Pendidikan Sekolah Ramah Anak Tahun Pelajaran 2016/2017. Pada awal ditetapkannya Sekolah Ramah Anak, Dinas Pendidikan Kota Depok dalam menunjuk sekolah sebagai piloting atau percontohan berdasarkan indikator sarana dan prasarana yang dinilai sudah memenuhi standar Sekolah Ramah Anak.

Penelitian ini menggunakan teori Michael Hill dan Peter Hupe (2002) dalam mengambarkan bagaimana implementasi Kebijakan Sekolah Ramah Anak di SMP Negeri 6 Depok yang meliputi aspke proses, hasil (output), dampak (outcome) dan hubungan sebab akibat (causal connection).

\section{1) Proses (process)}

Sejak 2015 sebelum adanya Kebijakan Sekolah Ramah Anak, SMP Negeri 6 Depok telah mempunyai kegiatan-kegiatan sekolah yang ternyata merupakan bagian dari kegiatan sekolah ramah anak dan telah menjadi pembiasaan atau budaya sekolah seperti penyambutan anak setiap hari oleh guru, budaya doa pagi dan budaya jumat bersih tersedianya taman bacaan untuk mendorong anak gemar membaca dan lainnya. SMP Negeri 6 Depok mendapatkan penghargaan Sekolah Adiwiyata tingkat Nasional juga menjadi Juara Sekolah Sehat mewakili kota Depok di tingkat Provinsi Jawa Barat.

Sejak tahun 2016.SMP Negeri 6 Depok telah menjadi piloting atau percontohan Sekolah Ramah Anak Implementasi Kebijakan Sekolah Ramah Anak telah dilaksanakan dengan baik. SMP Negeri 6 Depok telah berkomitmen dan mengikuti sosialisasi yang 
diselenggarakan oleh Dinas Pemberdayaan Anak, Masyarakat dan Keluarga (DPAMK) dan Dinas Pendidikan Kota Depok tentang Kebijakan Sekolah Ramah Anak.

Salah satu prinsip Sekolah Ramah Anak adalah non diskriminasi yang artinya setiap anak memiliki hak yang sama dalam mendapatkan pendidikan tanpa memandang status sosial, gender, ras, agama, perbedaan fisik dan sebagainya. Dalam upaya memenuhi kebutuhan pendidikan Anak Berkebutuhan Khusus (ABK), SMP Negeri 6 Depok telah menjadi sekolah inklusi yang melayani dan memenuhi Anak Berkebutuhan Khusus (ABK). Semua Anak Berkebutuhan Khusus (ABK) belajar bersama (membaur) dengan anak-anak normal lainnya namun ada perbedaan dalam perlakuan dan penilaian bagi anak berkebutuhan khusus (inklusi). Guru dan murid telah memahami bagaimana cara memperlakukan atau menghadapi anak yang berkebutuhan khusus sehingga anak tersebut merasa nyaman dan aman belajar di sekolah tanpa ada bullying dan kekerasan lainnya.

Sebagai Pembina, Kepala Sekolah SMP Negeri 6 Depok telah membentuk Tim Pelaksana Kebijakan Sekolah Ramah Anak yang meliputi Guru Bimbingan Konseling (BK), Guru Agama dan guru lainnya namun tugas fungsi belum dibuat secara tertulis. Para guru, anak murid dan orang tua sudah diberikan pemahaman tentang Kebijakan Sekolah Ramah Anak dan anti kekerasan melalui sosialisasi anti kekerasan, anti narkoba dalam proses belajar mengajar yang ramah anak. Belum ada kegiatan khusus untuk implementasi Kebijakan Sekolah Ramah Anak, semua kegiatan sosialisasi anti kekerasan atau parenting education bisanya disisipkan pada kegiatan sekolah lainnya yang melibatkan guru, murid dan orangtua karena keterbatasan anggaran.

Apabila terjadi kasus kekerasan di sekolah, para murid telah memahami mekanisme pengaduan yang telah tersedia. Pengaduan ditangani oleh Bidang Humas yang dikoordinir oleh Guru Bimbingan Konseling (BK). Jumlah Guru Bimbingan Konseling (BK) pada SMP Negeri 6 Depok sebanyak 3 (tiga) guru yang tidak sebanding dengan jumlah murid sebanyak 1.048 siswa. SMP Negeri 6 Depok telah menyediakan beberapa saluran komunikasi antara Peer Counselor untuk penanganan kasus kekerasan dari anak ke anak dan juga saluran komunikasi guru dan orang tua. Sekolah juga bekerja sama dengan Psikolog dan Kepolisian untuk menangani kasus yang sudah tidak bisa diselesaikan oleh pihak sekolah. Anak korban kekerasan akan diberikan terapi oleh untuk menghilangkan terauma akibat kekerasan yang terjadi sehingga korban bangkit dan mau bersekolah kembali. Bagi pelaku kekerasan dikenakan sanksi hukum yang ditangani oleh pihak Kepolisian dan diberikan pembekalan pendidikan sosial agar tidak melakukan tindakan kekerasan kembali.

\section{2) Hasil (output)}

Selama menjalani Kebijakan Sekolah Ramah Anak ada perubahan yang dirasakan oleh seluruh warga sekolah, khususnya anak murid. Sarana prasarana SMP Negeri 6 Depok seiring berjalan terus menerus menuju ke arah standard Sekolah Ramah Anak disesuaikan dengan kebutuhan anak. Tersedianya ruang

46 Copyright (C) 2019, Publik (Jurnal Ilmu Administrasi), Under the license CC BY-SA 4.0 ISSN: 2301-573X (Print), ISSN: 2581-2084 (Online) 
bermain terbuka bagi anak dan lingkungan sekolah yang bersih, sehat dan asri membuat murid menjadi senang dan nyaman berlama-lama di sekolah begitu juga anak yang memiliki kebutuhan khusus juga dapat menikmati proses belajar dengan aman dan nyaman tanpa diskriminasi. Murid sudah berpartisipasi aktif dalam memberikan masukan atau pendapat untuk kepentingan sekolah melalui Organisasi Siswa Intra Sekolah (OSIS) atau saluran komunikasi yang tersedia di SMP Negeri 6 Depok. Komunikasi antara guru, murid dan orang tua juga terjalin dengan baik sehingga siswa tidak malu ataupun takut untuk melaporkan tindak kekerasan yang terjadi pada diri mereka.

\section{3) Dampak (outcome)}

Kebijakan Sekolah Ramah Anak mendorong seluruh warga sekolah untuk peduli terhadap lingkungan sekolah dan anti kekerasan sehingga suasana di sekolah menjadi sehat, aman dan nyaman. Kondisi yang kondusif mendorong anak didik dapat berkembang dan berprestasi di sekolah, salah satunya pada awal tahun 2019, SMP Negeri 6 Depok Depok berhasil meraih 5 mendali (2 emas, 1 perak dan 2 perunggu) pada Olimpiade Olahraga Siswa Nasional yang digelar di Gelanggang Olah Raga (GOR) Depok II Tengah untuk lomba Pencak Silat katagori siswa Sekolah Dasar (SD) dan Sekolah Menegah Pertama (SMP) se-Kota Depok.

Bukan hanya anak didik saja yang berprestasi namun para guru juga terdorong untuk menjadi lebih bersemangat dalam mengajar. Proses belajar mengajar menjadi lebih menyenangkan, kreatif dan interaktif yang mendorong gairah belajar pada anak sehingga anak mudah menyerap ilmu yang disampaikan oleh guru. Upaya pembentukan karakter anak menjadi salah satu hal penting untuk menciptakan anak menjadi manusia yang bertanggung jawab dan berakhlak mulia yang lebih penting dari kecerdasaan. Bentuk pembentukan karakter misalnya mendidik anak untuk jujur, bertanggung jawab, displin.

\section{4) Hubungan sebab akibat (causal connection)}

Pendidikan merupakan alat membangun masa depan bangsa dan negara yang harus menjadi perhatian utama pemerintah. Kebijakan Sekolah Ramah Anak adalah salah satu upaya dari pemerintah untuk memberikan layanan pada tunas bangsa agar dapat mengenyam pendidikan dengan menyenangkan, aman dan nyaman. Keberhasilan jangka pendek dari upaya pemerintah melalui implementasi Kebijakan Sekolah Ramah Anak dapat ditunjukkan dengan berbagai prestasi yang diraih oleh insan-insan pendidikan, baik guru maupun siswa. Keberhasilan jangka panjangnya adalah pendidikan yang dapat meningkatkan taraf hidup dan kesejahteraan masyarakat. Keberhasilan atau kegagalan pelaksanaan kebijakan disebabkan dari dukungan dari semua pihak termasuk pemerintah pusat. Sekolah sebagai pelaksanaan Kebijakan Sekolah Ramah Anak memerlukan dukungan, pendampingan dan stimulan dari pemerintah pusat dan pemerintah daerah sebagai pembuat kebijakan. Stimulan atau dorong bisa berupa dana khusus yang diberikan kepada sekolah ramah anak untuk mengembangkan sarana dan prasarana sekolah yang ramah anak dan juga kegiatan sosialisasi dan memberikan edukasi secara mandiri 
tentang sekolah ramah anak atau anti kekerasan, anti Napza, makanan sehat, pareting education kepada warga sekolah, orang tua dan masyarakat di lingkungan sekolah.

\section{Analisis Implementasi Kebijakan Sekolah Ramah Anak di SMPN 6 Depok dari Aspek Komunikasi, Disposisi, Sumber Daya, Struktur Birokrasi, Hubungan Antar Instansi dan Lingkungan.}

Dalam menganalisis implementasi Kebijakan Sekolah Ramah Anak di SMP Negeri 6 Depok menggunakan teori perpaduan dari Edward III, G dalam Nugroho (2014) Shabbir Cheema dan Rondinelli dalam Subarsono (2005) yang menggali beberapa faktor yang terdiri dari komunikasi, disposisi, sumber daya, struktur birokrasi, hubungan antar instansi dan lingkungan.

\section{1) Komunikasi}

Penyampaian tujuan dan sasaran Kebijakan Sekolah Ramah Anak telah disampaikan oleh Pemda Depok melalui sosialisasi tentang Kebijakan Sekolah Ramah Anak anti kekerasan terhadap anak pada seluruh warga sekolah dan pelatihan kepada guru seperti tentang mengajar displin tanpa kekerasan. Komunikasi antara Kepala Sekolah, Guru, Murid dan Orang tua telah terlaksana dengan baik melalui parenting education yang disisipkan pada saat pertemuan sekolah dengan orang tua. Bimbingan dan arahan kepada murid yang disampaikan oleh Kepala Sekolah pada saat upacara sekolah dan guru pada saat pelajaran Bimbingan Konseling (BK). SMP Negeri 6 Depok juga menyediakan saluran-saluran komunikasi antara anak dengan anak, anak dengan guru dan guru dengan guru dan juga anak, guru dan orang tua.

\section{2) Disposisi}

Kebijakan Sekolah Ramah Anak disambut positif oleh seluruh warga SMP Negeri 6 Depok. Adanya Komitmen dari pihak Sekolah untuk menjalankan kebijakan ini dapat terlihat dari dibentuknya Tim Pelaksana Kebijakan Sekolah Ramah Anak oleh Kepala Sekolah SMP Negeri 6 Depok yang melibatkan Guru Bimbingan Konseling (BK), Guru Agama dan Komite Sekolah. Peningkatan pengetahuan dan kemampuan para pelaksana kebijakan yaitu guru, murid yang ditunjukan dengan proses belajar yang lebih menyenangkan, aman dan nyaman dan displin namun tanpa kekerasan. Adanya pengembangan proses belajar mengajar yang mampu membentuk karakter positif anak. Sikap guru yang dukungan implementasi Kebijakan Sekolah Ramah Anak di SMP Negeri 6 Depok dapat ditunjukan dari para guru berusaha bertanggungjawab untuk menjalankan implementasi Kebijakan Sekolah Ramah Anak selain itu komitmen juga ditunjukan dengan peningkatan layanan mengajar dengan lebih baik dan ramah kepada anak dan kualitas komunikasi yang lebih intensif dengan orang tua terkait dengan perkembangan pendidikan akademik anak.

\section{3) Sumber Daya}

Sarana prasarana sekolah sudah cukup memadai namun masih perlu pengembangan yang lebih lanjut untuk ke arah Sekolah Ramah Anak. Hal ini terlihat dari kondisi sekolah yang cukup memadai 
bagi siswa seperti tersedia lapangan sekolah sebagi tempat bermain anak di luar jam sekolah, toilet yang terpisah berdasarkan gender, toilet cantik untuk siswi yang datang bulan kantin sekolah yang cukup higienis dan aman bagi kesehatan, perpustakaan, Usaha Kesehatan Sekolah (UKS), ruang konseling dan sebagainya namun kondisi masih belum memadai apabila merujuk pada kondisi Sekolah Ramah Anak yang ideal karena terkendala anggaran sekolah yang terbatas karena sumber anggaran menggunakan dana Bantuan Operasional Sekolah (BOS) dan adanya regulasi dari pemerintah terkait pengelolaan anggaran belanja modal yang membatasi ruang gerak sekolah untuk mengembangkan sarana dan prasarana sekolah menjadi ramah anak. Terbatasnya jumlah guru yang menjadi tim pelaksana kebijakan dan padatnya aktivitas guru di sekolah sehingga program/kegiatan yang mendukung pelaksanaan kebijakan ini belum menjadi skala prioritas.

\section{4) Struktur Birokrasi}

Kepala Sekolah SMP Negeri 6 Depok telah membentuk tim pelaksana Kebijakan Sekolah Ramah Anak yang melibatkan para guru, komite sekolah, OSIS namun untuk tugas pokok dan fungsi dari masing-masing anggota tim pelaksana belum dibuat secara tertulis. Meskipun belum dibuat secara resmi, tim pelaksana telah berupaya menjalankan tugas dan fungsinya sesuai dengan pedoman Kebijakan Sekolah Ramah Anak.

\section{5) Hubungan antar Organisasi}

\section{Pemerintah Daerah Kota Depok melalui Dinas Pemberdayaan Anak, Masyarakat, dan Keluarga (DPAMK) telah melakukan sosialisasi Kebijakan Sekolah}

Ramah Anak dan pendampingan terhadap sekolah di kota Depok dengan berkoordinasi dengan Dinas Pendidikan Kota Depok sebagai instansi yang menetapkan Sekolah Ramah Anak. Dinas Pendidikan Kota Depok memberikan arahan dan pendampingan ke sekolah. Kepala Sekolah sebagai penanggungjawab pelaksanaan Kebijakan Sekolah Ramah Anak mendorong dan mengarahkan semua warga sekolah untuk mendukung pelaksanaan kebijakan. Hubungan antar organisasi belum bersinergi secara optimal sehingga kendala-kendala yang timbul pada saat pelaksanaan kebijakan tidak tersampaikan ke Pemerintah Pusat sebagai pembuat kebijakan sehingga masih banyak kebutuhan anak belum terpenuhi secara memadai.

\section{6) Lingkungan}

Perkembangan sosial anak-anak berada di bawah pengaruh keluarga, teman sebaya dan sekolah, dan lingkungan. Warga sekolah selain kepala sekolah, guru dan murid juga ada orang tua, penjaga sekolah (satpam), cleaning service, penjual makanan di kantin sekolah biasanya berasal warga sekitar lingkungan SMP Negeri 6 Depok. Pihak sekolah secara intensif telah melakukan pendekatan secara informal untuk memberikan pengarahan dan pengawasan mereka sehingga mendukung menciptakan lingkungan sekolah yang sehat, aman dan nyaman bagi seluruh warga sekolah khususnya siswa.

Implementasi Kebijakan Sekolah Ramah Anak didukung oleh Komunikasi yang baik dan lancar, sikap dan komitmen para guru dan seluruh warga SMP Negeri 6 Depok Kebijakan Sekolah Ramah Anak di SMP Negeri 6 Depok, hal ini ditunjukkan antara lain dengan adanya tim pelaksana 
kebijakan yang bertanggung jawab pada pelaksanaan kebijakan secara konsisten dan berkelanjutan; peningkatan kualitas pelayanan Pendidikan yang ramah anak tanpa diskriminasi dan terjalin koordinasi yang cukup baik antara Pemerintah Daerah Depok dengan Sekolah serta adanya dukungan positif seluruh warga sekolah, orang tua maupun masyarakat sekitar.

Seiring berjalannya Kebijakan Sekolah Ramah Anak ini banyak hambatan yang dihadapi antara lain terbatasnya anggaran sekolah untuk mendukung pengembangan sarana dan prasaran sekolah ke arah kondisi Sekolah Ramah Anak yang ideal dan terbatasnya jumlah guru serta padatnya aktivitas guru sehingga pelaksanaan kebijakan belum optimal dalam memenuhi standard Sekolah Ramah Anak.

\section{PENUTUP}

\section{Kesimpulan}

Berdasarkan hasil penelitian Implementasi Kebijakan Sekolah Ramah Anak di SMP Negeri 6 Depok telah berjalan dengan baik apabila dinilai dalam konteks proses, hasil (output), dampak (outcome) dan hubungan sebab akibat (causal connection). Pelaksanaan kegiatan telah memberikan hasil dan dampak potistif sesuai sasaran dan tujuan dari Implementasi Kebijakan Sekolah Ramah Anak. Meskipun sudah berjalan dengan baik masih perlu pengembangan baik dari segi sarana dan prasarana sekolah, sumber daya manusia, sumber finansial, dukungan dari seluruh warga sekolah, masyarakat, pemerintah pusat dan pemerintah daerah. Faktor-faktor yang mendukung adalah komunikasi yang baik dan lancar, sikap dan komitmen para guru dan seluruh warga, terjalin koordinasi yang cukup baik antara Pemda Depok dengan Sekolah serta adanya dukungan positif seluruh warga sekolah, orang tua maupun masyarakat sekitar. Namun sisi lain masih terdapat hambatan yang dihadapi yaitu terbatasnya anggaran untuk mendukung pengembangan sarana dan prasarana dan terbatasnya jumlah guru serta padatnya aktivitas guru sehingga pelaksanaan kebijakan belum optimal dalam memenuhi kebutuhan anak yang sesuai standard Sekolah Ramah Anak.

\section{Saran}

Kementerian

Pemberdayaan Perempuan dan Perlindungan Anak (PPPA) dan Pemerintah Daerah Kota Depok melakukan koordinasi dan evaluasi pelaksanaan Kebijakan Sekolah Ramah Anak yang lebih intensif sehingga memahami kompleksitas dan kendalakendala yang dihadapi di lapangan oleh para pelaksana kebijakan. Kementerian Pendidikan dan Kebudayaan diharapkan dalam merancang dan menetapkan kurikulum sekolah atau kebijakan Pendidikan agar menempatkan kebutuhan siswa atau anak sebagai prioritas utama. Dukungan dana, insentif dan perhatian serta pendampingan dari Kementerian Pemberdayaan Perempuan dan Perlindungan Anak (PPPA) dan Pemerintah Daerah (Pemda) Kota Depok sangat dibutuhkan untuk memperlancar pelaksanaan kebijakan ini.

Pihak SMP Negeri 6 Depok diharapkan secara konsisten melakukan sosialisasi, bimbingan tentang anti kekerasan pada seluruh warganya yaitu kepala sekolah, para guru, murid, orang

50 Copyright (C) 2019, Publik (Jurnal Ilmu Administrasi), Under the license CC BY-SA 4.0 ISSN: 2301-573X (Print), ISSN: 2581-2084 (Online) 
tua, penjaga sekolah dan lainnya agar dapat mendukung pelaksanaan Kebijakan Sekolah Ramah Anak. Pembentukan karakter anak melalui inovasi dan pengembangan metode belajar mengajar, kegiatan-kegiatan positif perlu ditingkatkan sehingga mendorong mental anak untuk bersemangat dalam belajar, berekspresi, berkreasi dan berprestasi, bertanggung jawab dan berakhlak mulia. Karakter yang telah terbentuk akan menjadikan budaya sekolah ramah anak di SMP Negeri 6 Depok. Kualitas dan intensitas komunikasi antara guru, murid dan orang tua harus lebih ditingkatkan sehingga tidak ada gap informasi, salah satunya dengan membuka banyak saluran komunikasi dan diskusi baik melalui komunikasi langsung atau tidak langsung.

\section{DAFTAR PUSTAKA}

Artadianti, Kiki. (2015). Implementasi Sekolah Ramah Anak (SRA) pada Sekolah Percontohan di SD Pekunden 01 Kota Semarang Sebagai Upaya Untuk Mendukung Program Kota Layak Anak (KLA). Journal Public Policy and Management Review, Volume 6, Nomor 3, Tahun 2017.

Djamaludin, Nanang, (2018). Cermin Ringkihnya KLA dan SRA di Kota Depok, diunggah pada tanggal 3 Maret 2019 dari https://www.watyutink.com/opini/Cer min-Ringkihnya-KLA-dan-SRA-diKota-Depok.

Dye, Thomas R. (2011). Understanding public policy. New Jersey: Pranticehall

Hill, M. and Hupe, P. (2009). Implementing Public Policy. Second Edition, SAGE Publications Inc., Thousand Oaks.
Kementerian Pendidikan dan Kebudayaan (Kemendikbud). (2017). Ikhtisar Data Pendidikan Tahun 2016/2017. Jakarta: Kementerian Pendidikan dan Kebudayaan (Kemendikbud).

KLA.id. (2017). Laporan Indonesia Pelaksanaan Konvensi Hak Anak diunduh dari http://www.kla.id/lapora $\underline{\text { n-indonesia-pelaksanaan-konvensi- }}$ hak-anak/

Nugroho, Riant. (2014). Public Policy (Teori, Manajemen, Dinamika, Analisis, Konvergensi dan Kimia Kebijakan). Edisi Kelima Revisi. Jakarta: PT. Elex Media Komputindo.

Peraturan Daerah Kota Depok Nomor 15 Tahun 2013 tentang Penyelenggaraan Kota Layak Anak

Peraturan Walikota Depok Nomor 10 Tahun 2017 tentang Pengembangan Kota Layak Anak.

Rahmi, Siti Suriati. (2014). Implementasi Kebijakan Publik. Unversitas Sumatera Utara.

Saraswati, Rika. (2015). Hukum Perlindungan Anak di Indonesia. Semarang: PT Citra Aditya Bakti

Sari, Ayu Kartika. (2017). Implementasi Program Sekolah Ramah Anak Dalam Penangulangan Kekerasan Pada Anak di SDN 3 Panggung Rejo Kabupaten Pringsewu. Unversitas Lampung.

Sekolah Anak.Com. (2018). Sekolah Ramah Anak di unduh dari https://sekolahanak.com/sekolahramah-anak.html

Subarsono, AG. (2005). Analisis Kebijakan Publik (Konsep, Teori dan Aplikasi). Cetakan VII . Yogyakarta: Pustaka Pelajar.

Subur. Qosim, Muhammad Nanang. Nugroho, Irham. (2018). Implementasi Sekolah Ramah Anak dalam 
Membentuk Budaya Sekolah di SDN Geger Tegalrejo. Prociding Konferensi Nasional ke-7, Asosiasi Program Pasca Sajana Perguruan Tinggi Muhammadiyah (APPPTMA), 2018.

Undang-Undang Nomor 23 Tahun 2002 tentang Perlindungan Anak

Undang-undang Nomor 35 Tahun 2014 tentang Perubahan atas UU Nomor 23 Tahun 2002 tentang Perlindungan Anak.

UNICEF. (2012). Child Friendly School. Diunggah dari https://www.unicef.org/ lifeskills/index 7260.html.

Utari, Ranti Eka. (2016). Implementasi Program Sekolah Ramah Anak di SMP Negeri 1 Tempura Kabupaten Magelang. Jurnal Kebijakan Pendidikan Edisi 7 Volume V Tahun 2016.

VOA Indonesia.com, KPAI : Kasus Kekerasan Anak dalam Pendidikan Meningkat Tahun 2018, diperoleh tanggal dari https://www.voaindonesia .com/a/kpai-kasus-kekerasan-anakdalam-pendidikan-meningkat-tahun2018/4718166.html

Winarno, Budi. (2016). Kebijakan Publik Era Globalisasi (Teori, Proses dan Studi Kasus Komparatif), Yogyakarta: CAPS.

Wuryandani, Wuri. (2018) Implementasi Pemenuhan Hak Anak melalui Sekolah Ramah Anak, Jurnal Civics: Media Kajian Kewarganegaraan Vol. 15 No. 1 Tahun 2018.

Yuliani, Wahyu Intan. (2015).

Implementasi Perwali Kota Surakarta Nomor 28D Tahun 2014 Tentang Sekolah Ramah Anak (Studi di SD ISSN: 2301-573X (Print), ISSN: 2581-2084 (Online)

Muhammadiyah 16 Karangasem dan SD Muhammadiyah Program Khusus (PK) Kota Barat). Universitas Sebelas Maret Surakarta. 